\title{
The effect of cluster thinning, cluster tipping, cluster shredding and defoliation at the flowering on the vegetative and generative vine performance from Kékfrankos Cv.
}

\author{
Fazekas, I..$^{*}$, Göblyös, J. ${ }^{2}$, Bisztray, Gy. D. ${ }^{1} \&$ Zanathy, G. ${ }^{1}$ \\ ${ }^{1}$ Corvinus University of Budapest, Institute of Viticulture and Oenology, Department of Viticulture \\ 1118 Budapest, Villányi út 29-43., Hungary \\ ${ }^{2}$ Eco Warranty Hungaria Ltd., 1033 Budapest, Miklós tér 1., Hungary \\ *author for correspondence, e-mail: istvan.fazekas@uni-corvinus.hu
}

\begin{abstract}
Summary: The cluster thinning is a method of the yield regulation. With the removal one part of the clusters, the yield pro leaf area will be lower, hereby the grape and wine quality will be improved.

The regulation of the yield can lead to further advantages: the ratio of the vegetative and generative performance of the vines will improve, the condition of the plants will better, the number of the physiological diseases can be reduced and the growth of the shoots and roots can be promoted. The grape growers make the cluster thinning almost exclusive by creating one cluster shoots. Usually the upper clusters are removed, because the sugar content of these second or third clusters will be lower. The cluster thinning is an easy task, can be done without special skills. It is an effective method improving wine quality, but its use can lead to other problems. The grapes try to compensate the removed clusters. Therefore the clusters will be bigger and thicker, but more sensitive to bunch rot. Moreover the treatment is expensive, because it needs manual work. It is worth to get acquainted and try the new yield regulation methods, which can help to avoid the occurring problems. Our aim is to show the results of our experiment, which was carried out in Eger, examining the red grape cultivar Kékfrankos. During our 4 years long experiment we compared the effects of cluster thinning, cluster shredding, cluster tipping and defoliation at the flowering, on the vegetative and generative vine performance.
\end{abstract}

Key words: yield regulation, cluster thinning, cluster tipping, cluster shredding, defoliation at the flowering, Kékfrankos

\section{Introduction}

In the scientific literature we can read about several new methods of ,green harvest”. Among them, the most familiar is maybe the cluster tipping. It is known, that with the cutting the end part of the clusters, the yield can be improved. This often used method can be applied not only in case of table grape production, but in case of vine production (Lörincz \& Barócsi, eds. 2010). During the splitting - dependent from the expected yield - the 30 or 50 percent of the clusters will be thrown away. Due to the cut, the clusters will be bigger and looser. (Schultz, 2003; Fader et al., 2004; Huber \& Bleyer, 2004; Huber, 2005; Kührer, 2007). The cluster tipping may have a positive effect not only in case of varieties with compact clusters, but also in case of varieties with looser clusters and bigger berries (Hafner, 2002). In the foreign praxis, mostly the bigger clusters or their basal cluster wings are cut (Fox, 2000). The optimal period for the work begins 2 or 3 weeks after bloom, and ends at the time of berry touch. In case of varieties with longer bunch stem, the end of the clusters can be nipped easy with hands (Petgen, 2005/A). It has to considered, that in case of cluster tipping bigger berries will develop during the first part of the fruit development (Fox, 2005; Kührer, 2007).

With the cluster tipping, not only the bunch rot and the acetification (Hafner, 2001) but also the bunch stem necrosis and the bunch parching can be overtaken effectively (Petgen \& Götz, 2004, Petgen, 2005/B; Raifer, 2010; Zanathy, 2011). In case of splitting every cluster, the treatment needs 75-110 hours manual work pro ha (Fader et al., 2004; Petgen, 2005/B). The necessary time for the work depends on the development stage of the clusters: in case of pea sized berries 50-70, in case of berry touch 70-90 working hours/ha, respectively. In case of thick clusters, the splitting can be done with difficulty; it needs 100 or 180 working hours/ha (Schumacher \& Hess, 2007). It is worth to note, that in case of cluster tipping, there isn't any time saving by the harvest, in contrast to forming one cluster shoots.

The cluster shredding bears a resemblance to berry thinning, which is one of the special summer pruning techniques. Berry thinning is made instead of scissors, with hands (with our thumb and forefinger), by rubbing off one part of the berries. Primarily, the first berries of the clusters can be rubbed off. The more berries are picked off, the more 
loose the structure of the cluster will be. According this, the thicker clusters has to be rubbed more radically (Petgen, 2005/A). The berry thinning has to be done after bloom and natural berry falling, at latest by forming pea-sized berries (Hanni, 2009). The optimal period of the thinning is relative short, because the bigger berries can be torn only with lesions. The berry thinning needs less working hours (30-40 hours/ha) than forming one cluster shoots (Petgen, 2005/B). The treatment results looser clusters and lighter, but bigger berries. The resistance of the clusters to bunch rot improves, so the yield can be harvested later. According the results of the trials, the cluster shredding -similarly to cluster thinningresults higher sugar content in the must, more phenolic materials and antocyanins, and higher resistance to bunch rot (Fox \& Steinbrenner, 2005; Fox, 2005; Petgen \& Götz, 2004; Petgen, 2005/A).

An indirect method of the yield regulation is the defoliation at the time of bloom. The method is based on the fact, that the assimilates for the blooms are produced by some neighbor leaves. The lack of these leaves results temporary malnutrition and poor fertility. (The defoliation before bloom results poor pollen fertility). Kozma (2003) discovered, that the defoliation before bloom results intensive masculinisation. The fruit set can be influenced by the defoliation, because with the removal of the first 3-4 leaves of the main shoots, the supply with assimilates of the bloom will be weakened. The defoliation at the flowering will result looser clusters, but bigger berries (Petgen \& Götz, 2004; Petgen, 2005/A). This method is worth to use in plantations with vigorous growth. Due to the treatment the microclimate in the cluster zone will be more optimal; the color and aroma stuff content of the berries will be higher. The skin of the berries, which are exposed to the sun from the beginning will be thicker, therefore the risk for sunburn will be lower (Prior, 2004). The defoliation with hands is not so hard like the defoliation with machines, but needs more manual work (25-50 hours/ha) (Petgen \& Götz, 2004; Petgen, 2005/B; Haas et al., 2007).

\section{Materials and methods}

The experiment was carried out in Eger, from 2005 to 2008 , in a plantation with clay loam soil. The climate of the four years was very different. In 2005 the vegetation period was 195 days long and the annual precipitation was $579 \mathrm{~mm}$. The major part of the precipitation was fallen in the vegetation period $(454 \mathrm{~mm})$. The botrytis infection was really notable in August, due to the effect of the $179 \mathrm{~mm}$ precipitation fallen. The active heat unit was $1292 \mathrm{C}$ and the number of sunny days 1955. The vegetation period was 207 days long in 2006. The annual rainfall was $436 \mathrm{~mm}$, but 371 $\mathrm{mm}$ was fallen from April to October. In the vegetation period the active heat unit was $1322 \mathrm{C}$ and the number of sunny days 1832 hours, while 2373 sunny days were registered in the whole year. The vegetation period in 2007 was 182 days long. $664 \mathrm{~mm}$ precipitation was fallen, $443 \mathrm{~mm}$ in the vegetation period. Similarly to the previous years, august was the wet month, with $143 \mathrm{~mm}$ rainfall. The active heat unit of the vintage was $1188 \mathrm{C}$. The number of the sunny hours was 2315, like in the previous years. In 2008, the vegetation period was 190 days long. $642 \mathrm{~mm}$ precipitation was fallen, $449 \mathrm{~mm}$ in the vegetation period. The active heat unit was $1098 \mathrm{C}$, while the number of the sunny hours 2672.

The study was carried out on Royat cordon vines with 3 $\mathrm{m}^{2}$ growing space. The plantation was settled in 2002. The investigated variety was 'Kékfrankos' (Kt.1), grafted in Teleki-Kober 125AA rootstocks. By the pruning 6 spurs were formed with 2 buds, in every year. The load was 4 buds/ $\mathrm{m}^{2}$. The height of the foliage wall was $160 \mathrm{~cm}$ in case of every treatment. The weed control was made by mowing in the interrows, while under the rows were used herbicides.

During the experiment the effect of several yield regulation methods (cluster tipping, cluster shredding, cluster thinning and defoliation at the flowering) on the vegetative and generative vine performance, were compared. Every treatment was located in 7 stocks, in four replications per treatment. The defoliation was made at the beginning of bloom, with the removal of the leaves located up, below and opposite to each bunches. The other treatments were made when berries reached pea size. During the cluster thinning one cluster/shoots were formed, with the removal of the upper ones.

The pruning weight was determined by measuring the pruned canes of three vines. (An Ohaus Defender 3000 scale was used). For measuring the yield an Ohaus Defender 3000 scale and a Sartorius basic scale were used. During harvest (2005. 10. 10.; 2006. 10. 09.; 2007. 09. 25.; 2008. 10. 11.) the number of the clusters (cluster/shoot), the yield $\left(\mathrm{kg} / \mathrm{m}^{2}\right)$ and the average weight of the clusters and berries $(\mathrm{g})$ were determined. The extract content was measured with a refractometer (DA-130N, Kyoto Electronics), using 100-100 berries pro treatment. The titrable acidity ( $\mathrm{g} / \mathrm{l})$ was determined by titrate $0,1 \mathrm{n} \mathrm{NaOH}$, using Bromthymol Blue indicator. The $\mathrm{PH}$ of the must was measured with a potentiometer (OP-211, Radelkis).

During the statistical analyses the ROPstat statistical program was used. The independent samples were compared from one aspect, with the program. If the deviation wasn't different, the means were compared with Tukey-Kramer test. In case of different means Games-Howell test was carried out.

Legend: C - control, CTip - cluster tipping, CS - cluster shredding, CT - cluster thinning, DF - defoliation at the flowering.

\section{Results}

Pruning weight: The effect of the crop regulation methods on the pruning weight was the most significant in 2007, in case of Kékfrankos variety (Table 1). The less pruning weight was measured in case of at bloom defoliated vines $(0,33 \mathrm{~kg})$. Between this treatment, the other three treatments (CTip - 0,51 kg, CS - 0,54 kg, CT - 0,51 kg) and 
Table 1. Effect of the treatments on the pruning weigth from $\mathrm{cv}$. Kékfrankos, 2005-2008.

\begin{tabular}{|c|c|c|c|c|}
\hline \multirow{2}{*}{ Treatment } & \multicolumn{4}{|c|}{ Pruning weigth (kg/vine) } \\
\hline & 2005 & 2006 & 2007 & 2008 \\
\hline Cluster & 0,60 & 0,42 & 0,51 & 0,54 \\
\hline thinning & a & a & a & a \\
\hline Cluster & 0,51 & 0,38 & 0,51 & 0,42 \\
\hline tipping & $\mathrm{a}$ & $\mathrm{a}$ & $\mathrm{a}$ & $\mathrm{a}$ \\
\hline $\begin{array}{l}\text { Cluster } \\
\text { shredding }\end{array}$ & $0,55 \mathrm{a}$ & $0,46 \mathrm{a}$ & $0,54 \mathrm{a}$ & $0,48 \mathrm{a}$ \\
\hline $\begin{array}{l}\text { Defoliation at } \\
\text { the flowering }\end{array}$ & $0,43 \mathrm{a}$ & $0,42 \mathrm{a}$ & $0,33 \mathrm{~b}$ & $0,33 \mathrm{a}$ \\
\hline Control & $0,44 \mathrm{a}$ & $0,33 \mathrm{a}$ & $0,49 \mathrm{a}$ & $0,4 \mathrm{a}$ \\
\hline Sign $^{2}$ & n. s. & n. s. & $* *$ & + \\
\hline
\end{tabular}

${ }^{1}$ Means within columns followed by different letters differ significantly at $\mathrm{p}<0,05$.

$2+, *, * *$, ns: significant at $\mathrm{p}<0,10,0,05 ; 0,01$, or not significant, respectively

the control $(0,49 \mathrm{~kg})$ significant differences were found. In 2005 little differences $(0,4-0,6 \mathrm{~kg} / \mathrm{vine})$ were found between the treatments. The trend was the same in 2006, with smaller differences $(0,33-0,46 \mathrm{~kg} / \mathrm{vine})$. In 2008 wasn't also notable difference between the treatments, except in case of cluster thinning and defoliation at the flowering. The difference between the treatments was $0,21 \mathrm{~kg} / \mathrm{vine}$, if $\mathrm{p}<0,10$.

Yield: The most important question is that the crop regulation methods how effective are in the several vintages. In case of the Kékfrankos variety significant differences were found between the yield of the treatments and the control vines in 2005, 2006 and 2008. In case of the control vines the average yield was $1,22 \mathrm{~kg} /$ vine in 2005 . The less yield was measured in case of cluster tipping $\left(0,42 \mathrm{~kg} / \mathrm{m}^{2}\right)$. Between the other treatments there wasn't found significant difference. Ezzahouani \& Williams (2003) have found also similar results: significant lower yield in case of cluster tipping. In 2006, $0,84 \mathrm{~kg} / \mathrm{m}^{2}$ and $0,21-0,42 \mathrm{~kg} / \mathrm{m}^{2}$ yield was measured in case of the control vines and the other treatments, respectively. (The fewer yield can be explained with the difficulties of the plant protection.) In 2007 the more yield was measured in case of the control vines, but there wasn't any significant difference between the several treatments and the control. In 2008 between the control $(1,09$ $\left.\mathrm{kg} / \mathrm{m}^{2}\right)$ and the cluster tipping $\left(0,66 \mathrm{~kg} / \mathrm{m}^{2}\right)$ was found significant difference, though the lower yield of the treated vines has shown the same pattern as in the previous years (Table 2).

According to the system of protected designation of origin in the Eger wine region, the maximum must yield can't overrun $60 \mathrm{hl}$ pro ha. This yield could realize only with fruit thinning methods, in our case. According to the regulation $\mathrm{Nr} .102 / 2009$ (VIII.5) $F$ VM, the 2,6 kg/vine yield exceeds the prescribed amount. Without the yield regulation methods, there wasn't any opportunity to make superior wine from 4 years in 2 . The above mentioned regulation maximizes the load in case of vines with protected denomination of origin in $6 \mathrm{buds} / \mathrm{m}^{2}$, while during the experiment only 4 buds/vine was used. According these results, the yield regulation methods play an important role in the practice of POD wine making.

The Ravaz index (yield/pruning weight ratio): The ratio of the vegetative and generative parts of the vine is usually described with the $y / n$ quotient, the ratio of the yield (y) and the weight of the pruned canes (n). If the bud load is optimal, the $y / n$ quotient is a least 4 , but maximum 6 . The higher rates suggest increased generative performance, while the lower rates refer to increased vegetative performance (Lörincz \& Zanathy, 2009). While in case of the control vines the $y / n$ quotient overrated 6 , in case of the cluster tipping, cluster shredding and cluster thinning the rates of the $y / n$ quotient stayed under 5 (Figure 1). The vines, which were defoliated at bloom, regarding the $y / n$ quotient were in bearing balance.

The average weight of the clusters: In 2005, the weight of the clusters from the control vines $(262,7 \mathrm{~g})$ overrated the cluster weight of the other treatments (CTip - 90,5 g, CS $139,9 \mathrm{~g}, \mathrm{CT}-168,6 \mathrm{~g}, \mathrm{DF}-155,1 \mathrm{~g})$. In 2006 and 2008, in

Table 2. Effect of the treatments on the yield, the cluster and the berry weight from cv. Kékfrankos, 2005-2008.

\begin{tabular}{|c|c|c|c|c|c|c|c|c|c|c|c|c|}
\hline \multirow{2}{*}{ Treatment } & \multicolumn{4}{|c|}{ Yield $\left(\mathrm{kg} / \mathrm{m}^{2}\right)$} & \multicolumn{4}{|c|}{ Cluster wt (g) } & \multicolumn{4}{|c|}{ Berry wt (g) } \\
\hline & 2005 & 2006 & 2007 & 2008 & 2005 & 2006 & 2007 & 2008 & 2005 & 2006 & 2007 & 2008 \\
\hline \multirow{2}{*}{ Cluster thinning } & 0,67 & 0,21 & 0,65 & 0,79 & 168,6 & 119,4 & 204,2 & 253,8 & 1,97 & 1,66 & 1,96 & 1,89 \\
\hline & $\mathrm{b}^{1}$ & $\mathrm{~b}$ & $\mathrm{a}$ & $\mathrm{ab}$ & $\mathrm{b}$ & a & $\mathrm{ab}$ & a & $a b^{1}$ & $\mathrm{a}$ & $\mathrm{a}$ & $\mathrm{a}$ \\
\hline \multirow{2}{*}{ Cluster tipping } & 0,42 & 0,27 & 0,65 & 0,66 & 90,5 & 79,8 & 181,3 & 108,2 & 1,95 & 1,82 & 1,91 & 1,91 \\
\hline & $\mathrm{b}$ & $\mathrm{b}$ & $\mathrm{a}$ & $\mathrm{b}$ & $\mathrm{b}$ & $\mathrm{a}$ & $\mathrm{ab}$ & $\mathrm{b}$ & $\mathrm{ab}$ & $\mathrm{a}$ & $\mathrm{a}$ & $\mathrm{a}$ \\
\hline \multirow{2}{*}{ Cluster shredding } & 0,57 & 0,31 & 0,68 & 0,83 & 139,9 & 99 & 170,3 & 148,8 & 1,87 & 1,85 & 1,78 & 1,73 \\
\hline & $\mathrm{b}$ & $\mathrm{b}$ & a & $\mathrm{ab}$ & b & $\mathrm{a}$ & $\mathrm{ab}$ & b & $\mathrm{ab}$ & a & a & $a b$ \\
\hline \multirow{2}{*}{$\begin{array}{l}\text { Defoliation at the } \\
\text { flowering }\end{array}$} & 0,72 & 0,41 & 0,61 & 0,64 & 155,1 & 89,1 & 157 & 145,5 & 1,74 & 1,72 & 1,85 & 1,61 \\
\hline & $\mathrm{b}$ & $\mathrm{b}$ & $\mathrm{a}$ & $\mathrm{b}$ & $\mathrm{b}$ & $\mathrm{a}$ & $\mathrm{b}$ & $\mathrm{b}$ & $\mathrm{b}$ & $\mathrm{a}$ & $\mathrm{a}$ & $\mathrm{b}$ \\
\hline \multirow{2}{*}{ Control } & 1,22 & 0,84 & 0,86 & 1,09 & 262,7 & 118,5 & 229,7 & 216,3 & 2,09 & 1,84 & 1,87 & 1,83 \\
\hline & $\mathrm{a}$ & $\mathrm{a}$ & $\mathrm{a}$ & $\mathrm{a}$ & $\mathrm{a}$ & $\mathrm{a}$ & $\mathrm{a}$ & $\mathrm{a}$ & $\mathrm{a}$ & $\mathrm{a}$ & $\mathrm{a}$ & $\mathrm{a}$ \\
\hline Sign $^{2}$ & ** & $* *$ & n. s. & + & $* *$ & n. s. & $*$ & $* *$ & + & n. s. & n. s. & *** \\
\hline
\end{tabular}

${ }^{1}$ Means within columns followed by different letters differ significantly at $\mathrm{p}<0,05$.

$2+, *, * *$, ns: significant at $\mathrm{p}<0,10,0,05 ; 0,01$, or not significant, respectively. 


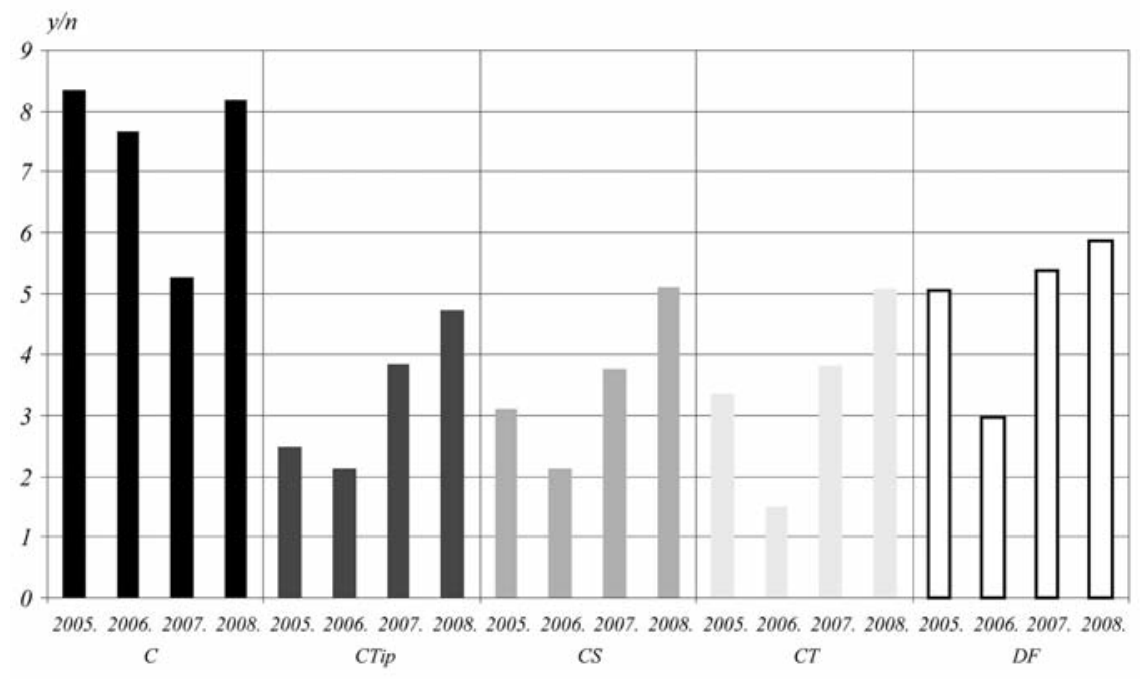

Figure 1. Effect of the treatments on the Ravaz index (y/n) from cv. Kékfrankos, 2005-2008. (C control, CTip - cluster tipping, CS - cluster shredding, CT - cluster thinning, DF - defoliation at the flowering)

case of cluster thinning and control vines the average cluster weight was the same (Table 2). In 2006, there wasn't significant difference between the treatments. (In this year, there was a downy mildew infection, which had a big effect on the vine performance). In 2007, there were significant differences regarding the average bunch weight, between the treatments. Compared with the control vines $(229,7 \mathrm{~g})$ and the cluster thinning (204,2 g), in case of the cluster shredding $(148,8 \mathrm{~g})$ and at bloom defoliated vines (157 g) the average cluster weight was lower. In 2008, the average bunch weight showed the same pattern as 2007 (108,2 g by cluster tipping, $148,8 \mathrm{~g}$ by cluster shredding and $145,5 \mathrm{~g}$ by defoliation at the flowering).

Soluble solids $\left({ }^{\circ} \mathbf{B x}\right)$ of the juice: From the view of the framers, one of the most important quality parameter is the sugar content or degree Brix of the juice. Nevertheless, it is an important parameter, during our experiment wasn't found significant differences. In 2005, in case of the defoliated vines the extract content of the juice was $23,27{ }^{\circ} \mathrm{Bx}$, significantly higher, than in case of the control vines $\left(23,27^{\circ} \mathrm{Bx}\right)$. In the other years, there wasn't found similar differences, although in 2006 the difference between cluster shredding $\left(24,64{ }^{\circ} \mathrm{Bx}\right)$ and defoliation at the flowering $\left(23,27{ }^{\circ} \mathrm{Bx}\right)$ was statistical confirmed. In 2007 and 2008, the degree Brix of the juices was almost equal (Table 3).

The $\mathbf{p H}$ of the juice: The differences in the $\mathrm{pH}$ of the juice during 2005 and 2006 could be statistical confirmed. In 2005 the lower $\mathrm{pH}$ was measured in case of the at bloom defoliated vines $(3,06)$, while in case of the control $(3,19)$ and cluster shredding $(3,16)$ higher $\mathrm{pH}$ was measured. The results have shown the same pattern in 2006: the lower $\mathrm{pH}$ was measured in case of the defoliated vines $(2,99)$, while the higher $\mathrm{pH}$ of the other treatments $(\mathrm{C}-3,04$, CTip - 3,08, CS - 3,09, CT - 3,05) showed significant difference (Table 3). In 2007 and 2008 there wasn't found significant difference between the treatments, the $\mathrm{pH}$ was without reference to the treatments 3,0-3,1.

Titratable acidity of the juice: In 2005 and 2008 the titratable acid content of the juice from the vines which were defoliated at bloom was significant different from the control vines (2005: C - 9,15 g/l, DF - 8,17 g/l; 2008: C - 9,09 g/l, $\mathrm{DF}-7,7 \mathrm{~g} / \mathrm{l})$. In 2006 only in case of the juice from cluster tipping $(8,32 \mathrm{~g} / \mathrm{l})$ was statistical different from the control $(9,5 \mathrm{~g} / \mathrm{l})$. In 2007 wasn't measurable difference in the titratable acidity content of the juices (Table 3).

The polyphenol and antocyanin content of the juice: The effect of the treatments on the polyphenol content of the juice $(2,11-2,96 \mathrm{mg} / 1 \mathrm{~g})$ was only in 2005 significant. The antocyanin content of the berries has changed remarkable only in one year, in 2005. The antocyanin content of the control berries $(1,60 \mathrm{mg} / 1 \mathrm{~g})$ was significantly different from

Table 3. Effect of the treatments on the Soluble solids (oBx), Titratable acidity (g/L) in Kékfrankos, 2005-2008.

\begin{tabular}{|c|c|c|c|c|c|c|c|c|c|c|c|c|}
\hline \multirow{2}{*}{ Treatment } & \multicolumn{4}{|c|}{ Soluble solids (oBx) } & \multicolumn{4}{|c|}{$\mathrm{pH}$} & \multicolumn{4}{|c|}{ Titratable acidity $(\mathrm{g} / \mathrm{L})$} \\
\hline & 2005 & 2006 & 2007 & 2008 & 2005 & 2006 & 2007 & 2008 & 2005 & 2006 & 2007 & 2008 \\
\hline Cluster thinning & $\begin{array}{c}22,54 \\
a^{1}\end{array}$ & $\begin{array}{c}24,3 \\
\mathrm{a}\end{array}$ & $\begin{array}{c}24,77 \\
\mathrm{a}\end{array}$ & $\begin{array}{c}24,24 \\
\mathrm{a}\end{array}$ & $\begin{array}{c}3,12 \\
\mathrm{ab}\end{array}$ & $\begin{array}{c}3,05 \\
\mathrm{ab}\end{array}$ & $\begin{array}{c}3,1 \\
\mathrm{a}\end{array}$ & $\begin{array}{c}2,95 \\
\mathrm{a}\end{array}$ & $\begin{array}{c}8,4 \\
\mathrm{a}\end{array}$ & $\begin{array}{c}9,7 \\
\mathrm{a}\end{array}$ & $\begin{array}{c}8,4 \\
\mathrm{a}\end{array}$ & $\begin{array}{c}8,5 \\
a b\end{array}$ \\
\hline Cluster tipping & $\begin{array}{c}23,02 \\
\mathrm{a}\end{array}$ & $\begin{array}{c}24,51 \\
\mathrm{a}\end{array}$ & $\begin{array}{c}24,61 \\
\mathrm{a}\end{array}$ & $\begin{array}{c}24,18 \\
\mathrm{a}\end{array}$ & $\begin{array}{c}3,13 \\
\mathrm{ab}\end{array}$ & $\begin{array}{c}3,08 \\
\mathrm{a}\end{array}$ & $\begin{array}{c}3,11 \\
\mathrm{a}\end{array}$ & $\begin{array}{c}3,09 \\
\mathrm{a}\end{array}$ & $\begin{array}{c}8,3 \\
\mathrm{a}\end{array}$ & $\begin{array}{c}8,3 \\
b\end{array}$ & $\begin{array}{c}8,4 \\
\mathrm{a}\end{array}$ & $\begin{array}{l}8,1 \\
\text { bc }\end{array}$ \\
\hline Cluster shredding & $\begin{array}{c}22,33 \\
\mathrm{a}\end{array}$ & $\begin{array}{c}24,64 \\
\mathrm{a}\end{array}$ & $\begin{array}{c}24,57 \\
\mathrm{a}\end{array}$ & $\begin{array}{c}24,6 \\
a\end{array}$ & $\begin{array}{c}3,16 \\
\mathrm{a}\end{array}$ & $\begin{array}{c}3,09 \\
\mathrm{a}\end{array}$ & $\begin{array}{c}3,09 \\
\mathrm{a}\end{array}$ & $\begin{array}{c}3,18 \\
\mathrm{a}\end{array}$ & $\begin{array}{c}8,4 \\
\mathrm{a}\end{array}$ & $\begin{array}{l}8,6 \\
a b\end{array}$ & $\begin{array}{c}8,2 \\
\mathrm{a}\end{array}$ & $\begin{array}{l}8,1 \\
\mathrm{bc}\end{array}$ \\
\hline $\begin{array}{l}\text { Defoliation at the } \\
\text { flowering }\end{array}$ & $\begin{array}{c}23,27 \\
\mathrm{a}\end{array}$ & $\begin{array}{c}23,44 \\
\text { a }\end{array}$ & $\begin{array}{c}24,38 \\
\mathrm{a}\end{array}$ & $\begin{array}{c}24,6 \\
\mathrm{a}\end{array}$ & $\begin{array}{c}3,06 \\
b\end{array}$ & $\begin{array}{c}2,99 \\
\mathrm{ab}\end{array}$ & $\begin{array}{c}3,09 \\
\text { a }\end{array}$ & $\begin{array}{c}3,03 \\
\mathrm{a}\end{array}$ & $\begin{array}{c}8,1 \\
\mathrm{a}\end{array}$ & $\begin{array}{c}9,7 \\
\mathrm{a}\end{array}$ & $\begin{array}{c}8,4 \\
\mathrm{a}\end{array}$ & $\begin{array}{c}7,6 \\
\mathrm{c}\end{array}$ \\
\hline Control & $\begin{array}{c}21,81 \\
\mathrm{a}\end{array}$ & $\begin{array}{c}24,36 \\
\mathrm{a}\end{array}$ & $\begin{array}{c}24,31 \\
\mathrm{a}\end{array}$ & $\begin{array}{c}23,78 \\
\text { a }\end{array}$ & $\begin{array}{c}3,19 \\
\mathrm{a}\end{array}$ & $\begin{array}{c}3,04 \\
b\end{array}$ & $\begin{array}{c}3,1 \\
\mathrm{a}\end{array}$ & $\begin{array}{c}3,1 \\
\mathrm{a}\end{array}$ & $\begin{array}{c}9,1 \\
\mathrm{a}\end{array}$ & $\begin{array}{l}9,5 \\
\mathrm{ab}\end{array}$ & $\begin{array}{c}8,4 \\
\mathrm{a}\end{array}$ & $\begin{array}{c}9,0 \\
\mathrm{a}\end{array}$ \\
\hline $\operatorname{Sign}^{2}$ & + & + & n. s. & n. s. & $* *$ & $* *$ & n. s. & n. s. & + & $* *$ & n. $\mathrm{s}$ & $* *$ \\
\hline
\end{tabular}

${ }^{1}$ Means within columns followed by different letters differ significantly at $\mathrm{p}<0,05$.

$2+, *, * *$ ns: significant at $\mathrm{p}<0,10,0,05 ; 0,01$, or not significant, respectively. 
Table 4. Effect of the treatments on the total phenolics and the anthocyanin content (mg/g fr wt) from Kékfrankos, 2005-2008.

\begin{tabular}{|c|c|c|c|c|c|c|c|c|}
\hline \multirow[t]{2}{*}{ Treatment } & \multicolumn{4}{|c|}{$\begin{array}{l}\text { Total phenolics } \\
\text { (mg/g fr wt) }\end{array}$} & \multicolumn{4}{|c|}{$\begin{array}{l}\text { Anthocyanin } \\
\text { (mg/g fr wt) }\end{array}$} \\
\hline & 2005 & 2006 & 2007 & 2008 & 2005 & 2006 & 2007 & 2008 \\
\hline \multirow{2}{*}{$\begin{array}{l}\text { Cluster } \\
\text { thinning }\end{array}$} & 2,75 & 3,64 & 3,25 & 3,08 & 2,22 & 3,39 & 2,77 & 2,43 \\
\hline & $a^{1}$ & $\mathrm{a}$ & $\mathrm{a}$ & $\mathrm{a}$ & $\mathrm{ab}$ & $\mathrm{a}$ & $\mathrm{a}$ & $\mathrm{a}$ \\
\hline \multirow{2}{*}{$\begin{array}{l}\text { Cluster } \\
\text { tipping }\end{array}$} & 2,96 & 3,33 & 3,58 & 3,14 & 2,63 & 3,12 & 3,23 & 2,44 \\
\hline & $\mathrm{a}$ & $\mathrm{a}$ & $\mathrm{a}$ & $\mathrm{a}$ & $\mathrm{a}$ & $\mathrm{a}$ & $\mathrm{a}$ & $\mathrm{a}$ \\
\hline \multirow{2}{*}{$\begin{array}{l}\text { Cluster } \\
\text { shredding }\end{array}$} & 2,52 & 3,46 & 3,61 & 2,91 & 1,98 & 3,22 & 3,05 & 2,33 \\
\hline & $\mathrm{a}$ & $\mathrm{a}$ & $\mathrm{a}$ & $\mathrm{a}$ & $\mathrm{ab}$ & $\mathrm{a}$ & $\mathrm{a}$ & $\mathrm{a}$ \\
\hline \multirow{2}{*}{$\begin{array}{l}\text { Defoliation at } \\
\text { the flowering }\end{array}$} & 2,78 & & 3,14 & 2,99 & 2,16 & 3,05 & 3,20 & 2,36 \\
\hline & $\mathrm{a}$ & 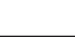 & $\mathrm{a}$ & $\mathrm{a}$ & $\mathrm{ab}$ & $\mathrm{a}$ & $\mathrm{a}$ & $\mathrm{a}$ \\
\hline \multirow{2}{*}{ Control } & 2,11 & 2,84 & 2,80 & 2,57 & 1,40 & 2,76 & 2,19 & 2,00 \\
\hline & $\mathrm{a}$ & $\mathrm{a}$ & $\mathrm{a}$ & $\mathrm{a}$ & $\mathrm{b}$ & $\mathrm{a}$ & $\mathrm{a}$ & $\mathrm{a}$ \\
\hline Sign $^{2}$ & + & n. s. & n. s. & n. s. & $*$ & n. s. & n. s. & n. s. \\
\hline
\end{tabular}

${ }^{1}$ Means within columns followed by different letters differ significantly at $\mathrm{p}<0,05$. ${ }^{2}+, *, * *$ ns: significant at $\mathrm{p}<0,10,0,05 ; 0,01$, or not significant, respectively.

the antocyanin content of the cluster tipping treatment $(2,63$ $\mathrm{mg} / 1 \mathrm{~g}$ ). In the other years of the experiment, it wasn't found any difference (Table 4).

Susceptibility to bunch rot and bunch stem necrosis: The treatments can be classified in two groups: reducing the number of clusters and reducing the size of the clusters. With the reduction of the bunch size the structure of the clusters will be looser, while with the reduction of the bunch number; the clusters will be thicker, which help to spread the bunch rot infection. The wet weather in the autumn of 2005 was adequate for proving the coherence between the cluster compactness and grey rot. In case of the cluster thinning $9 \%$, while in case of the control vines $11 \%$. of the clusters was botrytis infected. The less rotted berries were found in case of cluster tipping (3\%), but also in case of the defoliated vines was the ratio of botrytis infection low $(4 \%)$.

The bunch stem necrosis was notable in 2006. This year, in the other vine regions of the country was this physiological disease also observed. It is important to note, that the circumstances of bloom and fertilization wasn't optimal this year, because during May and June 202,3 $\mathrm{mm}$ precipitation was fallen. Regarding the measure of the disease, differences were found between the treatments: the clusters of the cluster thinning (34\%) and the control vines $(24 \%)$ were the most infected, while in case of the other treatments the number of the infected berries was under 1\% (Figure 2).

Working hours: The cluster thinning and the other new yield regulation methods don't need special knowledge. It can acquire with a little training. The treatments can be done parallel with other fitotechnical treatments (e.g. defoliation). (From this point of view, the most favorable solution is the defoliation at the flowering) The faster solution was the defoliation at the flowering (52s/vine), while the second was the cluster thinning ( $65 \mathrm{~s} / \mathrm{vine})$. For the cluster shredding 85 $\mathrm{s}$ was necessary pro vine, while the most time taking the cluster tipping (105 s/vine) was.

\section{Discussion}

The cluster thinning, maintaining one cluster/shoot is a common practice regulating the yield of the vine. However the economical and plant protection aspects of the fruit thinning need reconsideration. Some new advanced techniques of yield control can be advisable solution. In recent study cluster thinning, cluster shredding, cluster tipping and defoliation at flowering were compared in Eger, examining the red grape cultivar Kékfrankos. The effect of the yield control techniques on the vegetative and reproductive growth, quality indices (soluble solids, titratable acidity, $\mathrm{pH}$ value) of the fruit and the percentage of the bunch rot and -steam necrosis were recorded. Regarding the pruning weight there wasn't found any differences between the treatments. The greatest yield loss was recorded on the cluster tipping treatment. All of the examined treatments were suitable to obtain the yield limited by regulation of Superior cathegory of Denomination of Origin of Eger region. The must quality parameters improved with treatments, but the differences were modest. The sensitivity to grape rot, and the tendency to bunch steam necrosis was reduced by cluster tipping, -shredding and the defoliation at flowering treatments. The cluster thinned vines like controls was the sensitive. On economic aspect the defoliation at flowering was the most advisable practice for yield regulation. Time complete the treatment increased in the following order: cluster thinning, cluster shredding and finally cluster tipping.

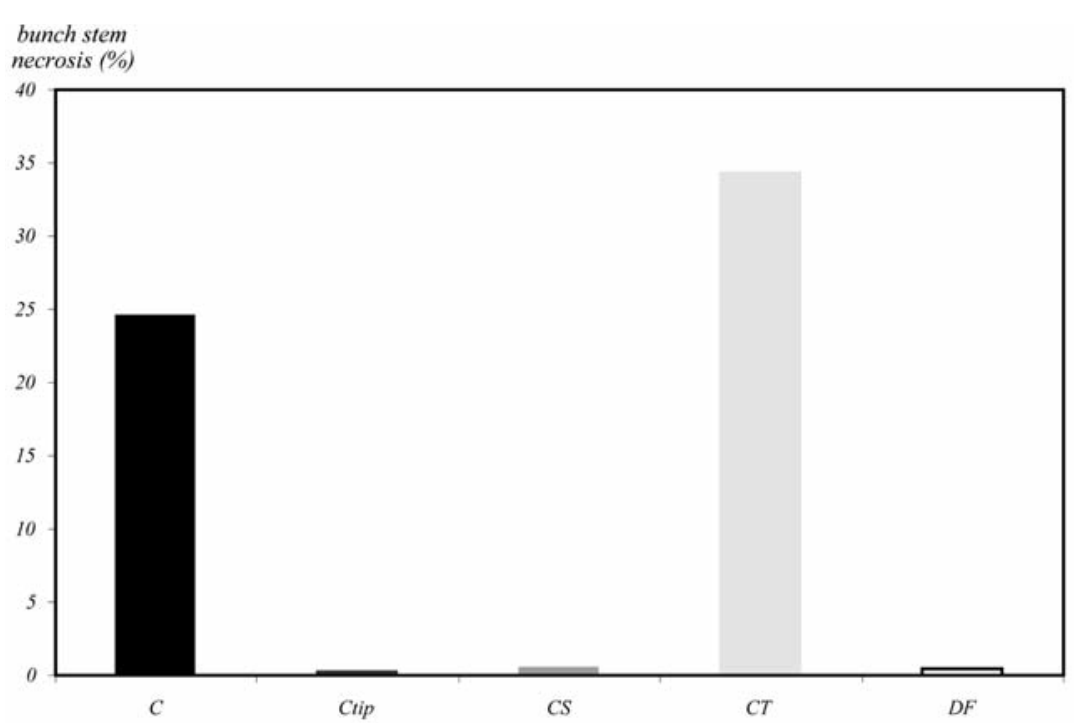

Figure 2. Effect of the treatments on the bunch steam necrosis (\%) from cv. Kékfrankos, 2006. (C - control, CTip - cluster tipping, CS - cluster shredding, CT - cluster thinning, DF - defoliation at the flowering) 


\section{References}

Ezzahouani, A., Williams, L. E. (2003): Trellising, fruit thinning and defoliation have only small effects on the performance of 'Ruby Seedless' grape in Morocco. J. Hort. Sci. Biotech. 78. (1): 79-83.

Fader, B., Hill, G., Spies, S. (2004): Traubenteilen zur Botrytisminderung im ökologischen Weinbau: Locker bleiben. Das Deutsche Weinmagazin. 8: 13-15.

Fox, R., Steinbrenner, P. (2005): Abstreifen - eine besonders interessante Methode. Rebe und Wein, 1: 18-20.

Fox, R. (2000): Ertragsregulierung mit gro er Wahrscheunlichkeit notwendig. Rebe und Wein. 7: 280-282.

Fox, R. (2005): Ergebnisse aus Versuchen 2004: Ertragsregulierung - ein Dauerthema? Das Deutsche Weinmagazin. 3: 16-19.

Hafner, P. (2001): Weniger Essigfäule durch Traubenteilen. Obstbau-Weinbau, Fachblatt des Südtiroler Beratungsringes. 6: 190-191.

Hafner, P. (2002): „Traubenteilen” hat sich bewährt. ObstbauWeinbau, Fachblatt des Südtiroler Beratungsringes. (7-8): 221-222.

Haas, E., Roschatt, C., Schweigkofler, W. (2007): Strategien zur Vermeidung von Botrytis- und Essigfäulen. Obstbau-Weinbau, Fachblatt des Südtiroler Beratungsringes. 6: 196-198.

Hanni, E. (2009): Mechanische Verfahren zur Ausdünnung im Weinbau. Obstbau-Weinbau, Fachblatt des Südtiroler Beratungsringes. 2: $85-88$.

Hill, G., Hill, M., Butterfass, J. (2003): Gibberelline - kleiner, weniger, besser? Das Deutsche Weinmagazin. 19: 32-35.

Huber, B., Bleyer, G. (2004): Neuansätze zur Vermeidung von Fäulnis an Trauben, Der Badische Winzer. 5: 46-49.
Huber, B. (2005): Zwei Strategien gegen Traubenkrankheiten. Der Badische Winzer. 5: 31-34.

Kozma P. (2003): A szőlő és termesztése II. Akadémiai Kiadó, Budapest

Kührer, E. (2007): Trauben teilen, Beeren abstreifen und pulsierender Luftstrom: Traubenausdünnung mittels alternativer Methoden. Der Winzer. 63. (4): 16-19.

Lőrincz A., Barócsi Z. eds. (2010): A szőlő metszése és zöldmunkái. Mezőgazda Kiadó, Budapest

Lőrincz A., Zanathy G. (2009): Szőlőtemesztés. Egyetemi jegyzet. Budapesti Corvinus Egyetem, Kertészettudományi Kar, Budapest

Petgen, M., Götz, G. (2004): Teilentblätterung 2004. Mehr Nutzen oder Schaden? Das Deutsche Weinmagazin. 2: 28-32.

Petgen, M. (2005/A): Weinbaulichen Ma nahmen zur Fäulnisvermeidung. Der Winzer. 3: 14-17.

Petgen, M. (2005/B): Möglichkeiten und Grenzen der Ertragsregulierung. Der Winzer. 5: 13-15.

Prior, B. (2004): Eingriffe in die Laubwand der Rebe: Ertrag und Qualität. Schweiz. Z. Obst-Weinbau. 11: 9-13.

Raifer, B. (2010): Ergebnisse zur Traubenwelke $2010 \mathrm{im} \mathrm{Licht} \mathrm{des}$ internationalen Wissensstandes. Schweiz. Z. Obst-Weinbau. 2: $40-42$.

Schultz, H. R., Kohler, D., Fox, R. (2003): Eine Erfolg versprechende Ausdünnungsvariante: Trauben teilen. Das Deutsche Weinmagazin. 15: 22-25.

Schumacher, P., Hess, S. (2007): Vorteile des Traubenteilens. Schweiz. Z. Obst-Weinbau. 11: 6-9.

Zanathy G. (2011): Fürtfonnyadás. Agrofórum. 8: 100-103. 102/2009. (VIII. 5.) FVM rendelet az Egri borvidék védett eredetü borairól 